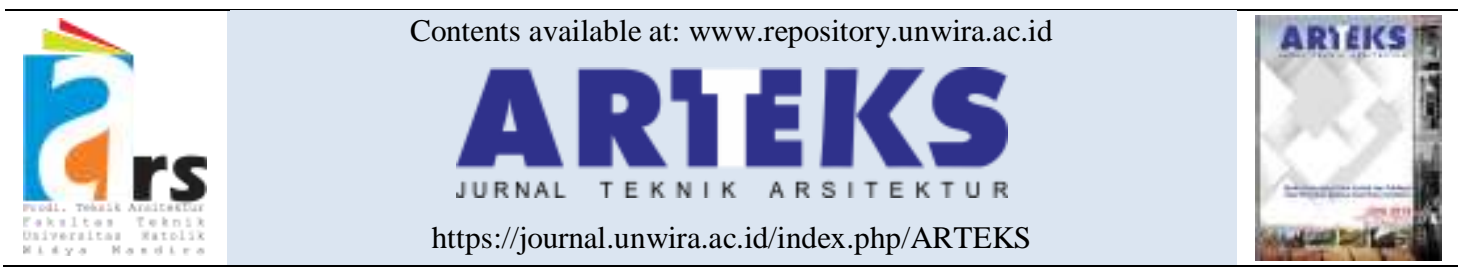

Research paper

doi: $10.30822 /$ arteks.v6i2.698

\title{
The effectiveness of daylighting through the toplighting design in large-volume building models
}

\author{
Ariani Mandala*(D, E. B. Handoko Sutanto, Amirani Ritva Santoso \\ Architecture Study Program, Faculty of Engineering, Universitas Katolik Parahyangan \\ Jl. Ciumbuleuit no. 94, Bandung, Indonesia
}

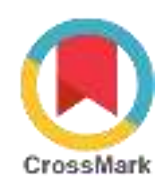

\begin{tabular}{|c|c|}
\hline ARTICLE INFO & ABSTRACT \\
\hline $\begin{array}{l}\text { Article history: } \\
\text { Received October } 14,2020 \\
\text { Received in revised form Dec. } 17,2020 \\
\text { Accepted February } 18,2021 \\
\text { Available online August } 01,2021\end{array}$ & $\begin{array}{l}\text { The utilization of daylighting as an effort to reduce the usage of } \\
\text { building energy needs to be optimized. This is because, low-rise } \\
\text { buildings with large volumes require specific strategies for proper } \\
\text { light distribution throughout the space. Hence, this study aims to } \\
\text { explore and compare the effectiveness of daylighting in the openings }\end{array}$ \\
\hline $\begin{array}{l}\text { *Corresponding author: Ariani Mandala } \\
\text { Architecture Study Program, Faculty of } \\
\text { Engineering, Universitas Katolik } \\
\text { Parahyangan, Indonesia } \\
\text { Email: ariani.mandala@ unpar.ac.id } \\
\text { ORCID: https://orcid.org/0000-0002-1252- } \\
3496\end{array}$ & $\begin{array}{l}\text { design of skylight, roof monitor, and sawtooth in large-volume } \\
\text { buildings in Bandung. The effectiveness is assessed by examining } \\
\text { lighting performance based on distribution patterns, the value of } \\
\text { Daylight Factor (DF), and the Coefficient of Uniformity (CU). } \\
\text { Experimental research method with simulation program known as } \\
\text { Velux Daylight Visualizer } 3.0 \text { is used to present and analyze the } \\
\text { lighting data. The results showed that the type, position (openings' } \\
\text { height and distance), as well as the opening direction affected the } \\
\text { distribution patterns and daylighting performance. Based on the } \\
\text { simulation, the skylight opening is the most effective in meeting the } \\
\text { standard value of Daylight Factor (> } 2 \% \text { ) and Coefficient of } \\
\text { Uniformity (CU min. O.3 and DF min. 0.8\%). Thus, space and } \\
\text { openings model with a percentage roof area of } 16.3 \% \text { in the } \\
\text { simulation can be used as a reference for large-volume buildings } \\
\text { because, it meets the requirements of Daylight Factor value and } \\
\text { sufficient Coefficient of Uniformity. }\end{array}$ \\
\hline
\end{tabular}

\section{Introduction}

Daylighting is an important factor in building design in the tropical countries because, sun exposure is abundant throughout the year (Anthony et al. 2020). Based on this, passive design can be carried out by adjusting the light holes openings in order to maximize the potential of daylighting and reduce the lamp's utilization to save energy (Zain-Ahmed et al. 2002). With the right strategy, the daylighting implementation can reduce the utilization of the electrical energy in the buildings to 40-60\% (Lawrence et al. 2008).

The researches on daylighting design for the visual comfort in buildings are often carried out for office functions but are very limited to industrial buildings with higher electricity consumption (Chen et al. 2014). For instance, in low-rise buildings such as industrial buildings with large volumes, daylighting strategies are effective in reducing energy instead of using artificial lighting (Lapisa et al. 2020). Openings in the roof of buildings have the potential to permit daylighting to reduce energy, but can also increase heat (Lapisa et al. 2020). Therefore, processing openings need to be adjusted to minimize negative impacts and improve daylighting performance for user's comfort (Rahmah and Aqli 2020).

There are different types of toplighting, namely, the skylight, roof monitor, and sawtooth (Lechner 2008). Researches have been widely carried out on potential opening design strategies for skylight types both in comparison of number and openings area, as well as the glazing types 
used (Al-Obaidi, Ismail, and Abdul Rahman 2014; Lapisa et al. 2020; De Luca et al. 2018; Nezamdoost et al. 2017). Based on this, the analysis of various dimensions on sawtooth openings shows the potential for the types of openings to be applied in industrial buildings (Asdrubali 2003). For instance, on flat roofs in tropical areas, skylight types with additional reflectors are most effective at illuminating the room and reducing heat, while the roof monitor type can produce the evenest light distribution but has the potential to receive higher heat (Beltran 2005).

In this paper, various types of toplighting were explored to determine the daylighting performance in large-volume buildings in Bandung. The roof is slanted in order to respond to the tropical climate in Indonesia with high rainfall. Likewise, the positions and variations in the openings types in the roof plane are also varied to determine the most effective strategy. The analysis is studied from the mapping of light distribution patterns to the zoning formation in space and daylighting performance analysis (using Velux Daylight Visualizer 3.0 software) in the form of fulfillment with light illumination standards reviewed from Daylight factor (DF) and Coefficient of Uniformity (CU) values. Opening design exploration is included in passive design control which is one of the early strategies for energy-efficient building design.

Over the past 50 years, light science has shifted from physics to engineering and has subsequently become part of building environment design (Mansfield 2018). The urgency of using daylighting as a material in architectural design has been recognized by architects for a long time. Previous researches have surveyed how to respond to the need for daylighting (Farley and Veitch 2001), and it all led to the same conclusion that daylighting is essential and preferred. In addition, the application of an optimal daylighting system has been shown to provide various benefits for improving the health, productivity, and safety of the building users (Edwards and Torcellini 2002; Lawrence et al. 2008; Heschong 2002; Barret 2009; Singh 2018).

On the other hand, the parameters affecting daylighting include, sky conditions and building data (Mandala, Ritva Santoso, and Gunawan 2016), while the data rsegarding buildings are, site and building conditions (from facades processing to inner space). The opening to the north or south is the best building mass orientation in the geographical location of Bandung City. This is because the sunlight obtained has good quality, relative irradiation time throughout the day, with a smaller radiation level when compared to other orientation directions. Basically, the position, geometry, and opening shape determine which parts of the space get direct sunlight and produce light distribution patterns.

Also, the arrangement of the inner space and the color utilization will affect the light reflection that will occur (Singh 2018). Reason being that, the light colors does not only function as reflection areas, but also diffuse light to reduce dark shadows, glare, and light that is too bright. Hence, the color arrangement of the interior enclosure will have a significant effect on illumination and light distribution (Egan and Olgyay 2001).

The three basic forms of including natural light into buildings are, side openings, upper, and atriums (Egan and Olgyay 2001). One of the daylighting strategy is to place the opening in a high place (roof or higher wall area) to get a brighter skylight (Phillips 2004). The high aperture position can also increase the reach of light into more space and get a more even light distribution (Egan and Olgyay 2001). According to the rule of thumb, the distance between the light holes in the roof should be 1-1.5 times the ceiling height (Egan and Olgyay 2001). To increase illumination, light openings in the horizontal roof plane receive more light than vertical openings but can cause haunting, glare, and heat problems (figure 1).

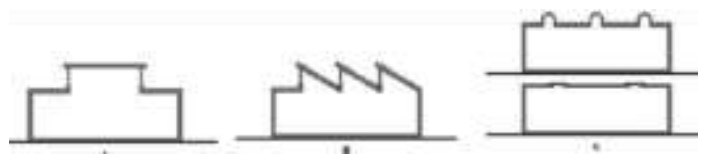

Figure 1. Types of uppers openings (from left to right: roof monitor, sawtooth, skylight)

Source: (Lechner 2008)

There are various types of uppers opening, namely roof monitor, sawtooth, and skylight. The roof monitor opening is done by increasing the roof height and adding a vertical or inclined opening element. This strategy has the potential to reduce overheating compared to the skylight types (Lechner 2008). On the other hand, the sawtoothtype composition is used to distribute natural light uniformly over a large space. The orientation of the openings in this type can be determined, 
therefore its position can take the maximum natural light and reduce the entry of heat radiation into space.

The various forms of skylights consist of the dome, pitched, and flat (Lechner 2008). Although it is the most economical in the installation stage, yet this opening has the potential to cause uneven distribution of light, high heat, and glare. This is because, it receives direct sunlight during the day, hence the energy consumption for cooling is greater (Ander 2003). The skylight opening type is more effective at increasing the illumination value, but the light uniformity is worse than other types. Meanwhile, the sawtooth type (with twoway openings orientation) has the opposite performance (Ali 2014).

The earliest, easiest, and most commonly used natural light indicator is the Daylight Factor (DF) value because, it is calculated in the worst sky conditions (overcast sky) (Acosta et al. 2015). The Daylight Factor is calculated by comparing the values of indoor and outdoor illumination (in evenly distributed sky conditions), and the comparison ratio is expressed as a percentage. The average DF value requirement is around $2 \%$ for industrial buildings such as sports halls, laboratories, multipurpose halls, etc. (BRE Global 2013).

The three components in calculating daylighting are the sky, the outer, and the inner reflection (Barbrow 1964). Although the skylight component is the largest determinant of the DF value, the reflection also contributes to the illumination (Acosta et al. 2015). A space painted white (reflection level 70\%) can increase the Daylight Factor value up to 3 times compared to the one with black paint (Mandala and Ritva Santoso 2018).

Apart from illumination, the requirement for good daylighting quality is evenly distributed throughout the indoor space (Mandala 2020). One of the design strategies for equality in light distribution is by positioning openings and selecting the interior material. Light distribution measurements can be stated in the Coefficient of Uniformity (CU), which is the ratio of the minimum value to the maximum or average $\mathrm{DF}$ in a space (Iversen et al. 2013). The minimum standard of BRE (BRE Global 2013) for equitable distribution is $\mathrm{DF}$ min/average $=0.3$ or $\mathrm{a}$ minimum DF value of $0.8 \%$.

Although, previous research have been dominated by the exploration of each opening type (especially skylights) in the climate context, based on different locations. The comparison of the effectiveness of the three toplighting has not been widely studied, especially in the sloping roof shape with variations in the openings' placement position in the roof plane. Therefore, this research can contribute to being a reference for designers to determine the type and position of roof openings in optimizing the inclusion of natural light in wide-span building models in Bandung City.

\section{Method}

This section consist of an exploratory research with experimental methods in which the spatial model simulated is based on several considerations. For instance, the efficient spans (reinforced concrete structures) for industrial buildings are 10-30 m (Neufert and Neufert 2000). In accordance to the sports infrastructure standards from the Regulation of the Minister of Youth and Sports (Permenpora), the minimum size of a type $\mathrm{C}$ building (general) is $20 \mathrm{~m}$ wide and 9m high (2014) (Kementrian Pemuda dan Olahraga RI 2014). This $9 \mathrm{~m}$ is also the maximum height of the single-span of shed type wide building (Neufert and Neufert 2000). The building length considers the provisions for the industrial plot module system application of width: length $=2: 3$ or $1: 2$ for effectiveness (2010) (Kementrian Perindustrian RI 2010). Therefore, the space model used is $40.00 \mathrm{~m}$ (length) x $20.00 \mathrm{~m}$ (width) $\times 9.00 \mathrm{~m}$ (height). The space volume is large enough for industrial buildings and meets the minimum height requirements for public sports buildings. Due to the physical aspects of light, the calculation results and daylighting patterns are also identical when applied to different scale building models with the same proportion.

The model space, openings, and parameters used in the simulation are detailed as follows:

1) The angle of the roof (typical slope of the roof in the tropics) $=30^{\circ}$;

2) The space color is white with a reflection value of $80 \%$;

3) Location setting $=$ Bandung city $\left(6^{\circ} \mathrm{LS}, 107^{\circ}\right.$ East);

4) North-South opening orientation;

5) The height of the work plane from the floor = $0.85 \mathrm{~m}$; 
6) The aperture module uses the product standard from the Velux program, with a length $\mathrm{x}$ width $=94.2 \times 160 \mathrm{~cm}\left(\right.$ glass area $\left.=0.94 \mathrm{~m}^{2}\right)$. Total modules in 1 building $=80$ modules (longitudinal linear arrangement) with glass transparency $=70 \%$;

7) Specification of 'Daylight Factors' rendering type in 'overcast' sky conditions with 'high' render quality.

skyliaght
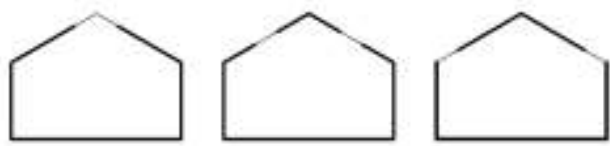

roof manitor
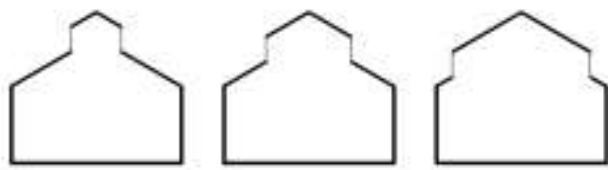

saw tooth

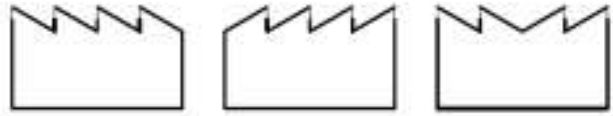

Figure 2. Experimental variants of exploration types and top lighting positions
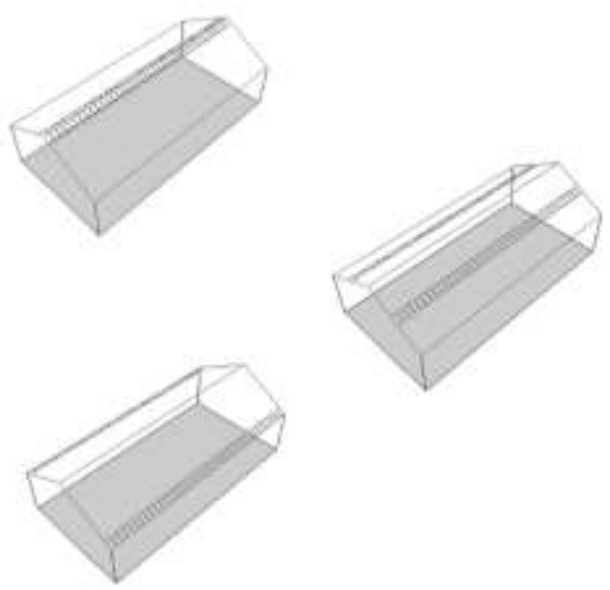

Figure 3. The module openings arrangement in the skylight type

The simulation of daylighting performance is done on a computer with Velux Daylight Visualizer software version 3.0. The reference DF value is $2 \%$ with standard $\mathrm{CU}=0.3$ or $\mathrm{DF}$ min. $0.8 \%$. The analysis of daylighting performance was studied from the results of visualization and computation, and was calculated in the form of light distribution patterns, Daylight Factor (DF) values, and $\mathrm{CU}$ values as seen in table 1 .

Table 1. Data collection techniques

\begin{tabular}{|c|c|c|c|}
\hline $\begin{array}{l}\text { Type of } \\
\text { data }\end{array}$ & $\begin{array}{l}\text { Top } \\
\text { lighting } \\
\text { type }\end{array}$ & $\begin{array}{l}\text { Variants of } \\
\text { position and } \\
\text { opening } \\
\text { direction } \\
\end{array}$ & $\begin{array}{l}\text { Data } \\
\text { collection } \\
\text { method }\end{array}$ \\
\hline \multirow{3}{*}{$\begin{array}{l}\text { Light } \\
\text { distribution } \\
\text { pattern } \\
\text { (CU) and } \\
\text { DF value } \\
\text { (min, max, } \\
\text { and } \\
\text { average) }\end{array}$} & Skylight & $\begin{array}{l}\text { Position of } \\
\text { upper, middle, } \\
\text { and roof } \\
\text { openings }\end{array}$ & \multirow{3}{*}{$\begin{array}{l}\text { Computing } \\
\text { simulation } \\
\text { using } \\
\text { Velux } \\
\text { daylight } \\
\text { visualizer } \\
3.0 \\
\text { software }\end{array}$} \\
\hline & $\begin{array}{l}\text { Roof } \\
\text { monitor }\end{array}$ & $\begin{array}{l}\text { The distance } \\
\text { between the } \\
\text { openings is } 6 \\
\mathrm{~m}, 10 \mathrm{~m} \text {, and } \\
16 \mathrm{~m}\end{array}$ & \\
\hline & Sawtooth & $\begin{array}{l}\text { The opening } \\
\text { direction is to } \\
\text { the North, } \\
\text { South, and a } \\
\text { combination of } \\
\text { both }\end{array}$ & \\
\hline
\end{tabular}

\section{Result and discussion}

Comparison of DF value and light uniformity on skylight type aperture

Table 2. Comparison table of light contours and skylight-type daylighting visualization

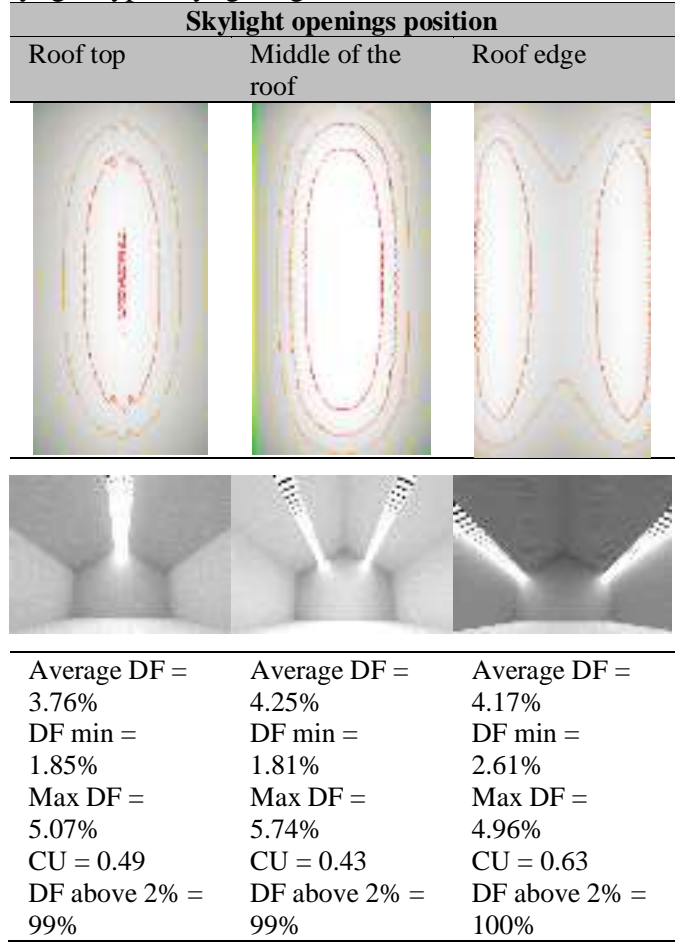




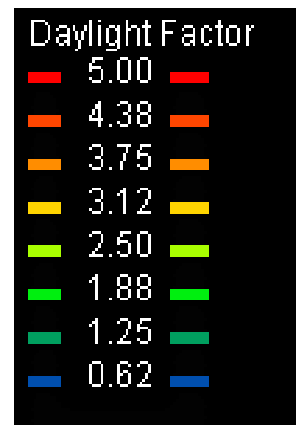

Figure 4. Color description of light contours

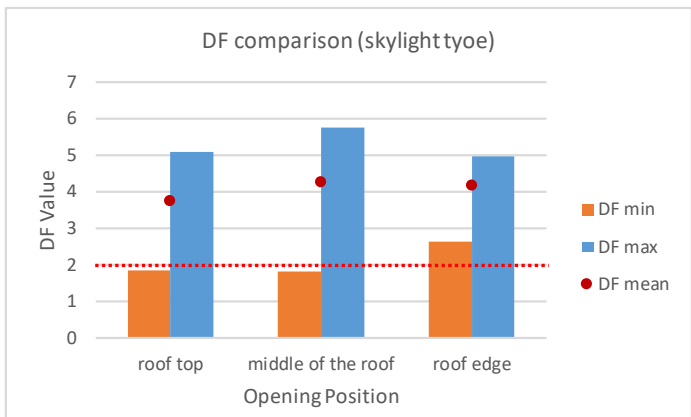

Figure 5. Comparison graphic of DF value on skylight type

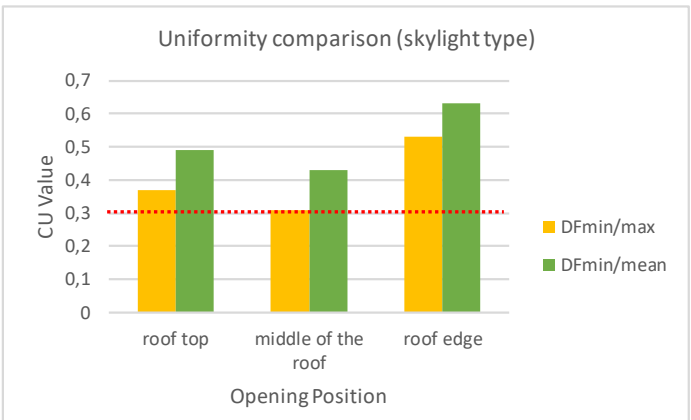

Figure 6. Comparison graphic of the uniformity value of the skylight type

The light distribution pattern formed, follows the placing openings (linear to the longitudinal direction of the building). Skylight types 1 and 2 are higher in the part directly below the opening with a light gradation to the edge of the building. While the type 3 has a different distribution pattern because, the distance between the openings is far enough to divide the space into two (symmetrical), according to the opening position. Also, skylight type 1 and 2 are suitable for a spatial planning that tends to be centered (activity in the middle of the room), while the one positioned on the edge is suitable for a linear spatial arrangement with a circulation path in the middle of the space (dividing space into two functional zones).

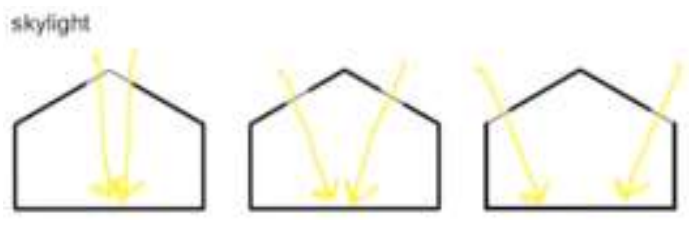

Figure 7. The light distribution visualization of the skylight opening type

The value of Daylight Factor is higher in skylights type 2 (average DF $=4.25 \%$ ), with the opening position in the middle of the roof/space because, the opening height is lower than its position at the rooftop. Also, the opening position in the middle of the space causes the light accumulation from the two openings to gather in the middle, thus, the maximum and average DF value is higher than the skylight type 3 . The skylight on the roof edge causes the middle area of the space to be dark therefore, the average DF value is smaller. Consequently, these three types of skylight openings are quite capable of meeting the standard DF value of min. $2 \%$ for office, classroom, or stadium function in almost all rooms with $99-100 \%$ fulfillment. It should be noted that the average Daylight Factor (DF) value in the three skylights types is quite high, reaching $3-4 \%$. Hence, to reduce the potential for glare and heat due to direct sunlight, a reflector can be added to the skylight or change the glass material to opaque which can also improve light distribution.

All the three spaces have sufficient light uniformity values that are above the general light uniformity requirements (above 0.3). For instance, high indoor reflection value has a big contribution to produce light uniformity, and skylight type 3 has the highest value (CU min/average $=0.63$ ). The position of the openings is on the edge of the roof with a distance of $16 \mathrm{~m}$. Distance ratio between the opening and the room height (16: 9) is 1.78 close to the strategy of toplighting which ensure uniformity in light distribution (1-1.5 x). In this type, skylight directly hits the wall element which then becomes a reflector to help spread light evenly throughout the space. Skylight type 2 also has an opening distance according to the strategy of $1.1 \mathrm{x}$ the height of the space. However, the width of the building is large enough therefore, light penetration does not reach the edges of the 
building. Furthermore, the two toplighting positioned in the middle of the space produce a maximum DF value greater than the skylight type 1 (the distance between the opening and the working plane is further away). This results in greater light contrast when compared to other types of skylights.

Comparison of DF value and light uniformity on openings with roof monitors' type

Table 3. Comparison table of light contours and daylighting visualization on roof monitor type
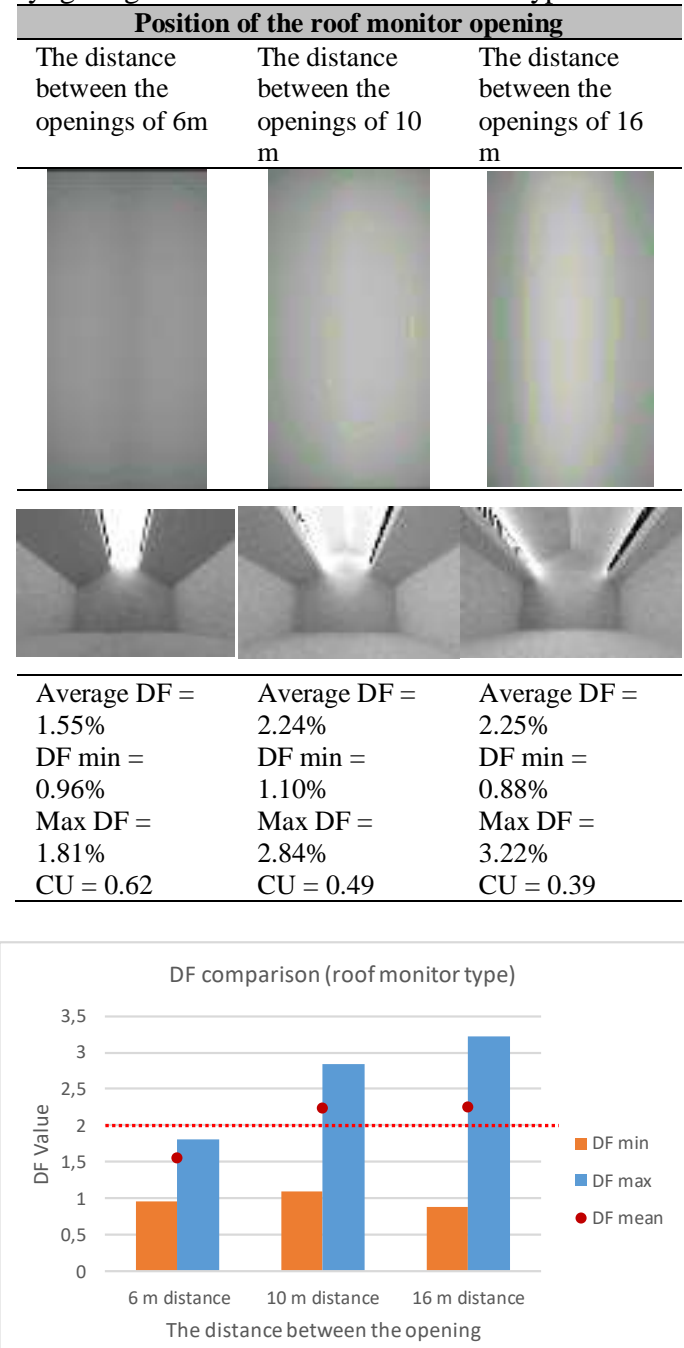

Figure 8. Comparison graph of DF value on the roof monitor type

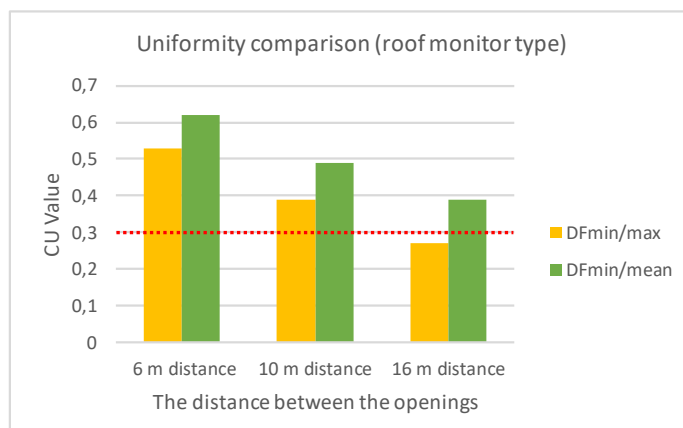

Figure 9. The comparison graph of the light uniformity value on the roof monitor type

The opening position on the roof monitor is in the vertical plane of the building, while that of skylight type is in the horizontal plane. This causes the light distribution pattern formed to be different. Also, in the roof monitor types 1 and 2, the light is higher in the part directly below the opening with a light gradation to the edge of the building. The roof monitor type 1 has a different distribution pattern because, the vertical plane position of the openings is close together, therefore, the light penetration is directed far to the edge of the space, thereby dividing it into two. The roof monitor type 2 and 3 are more suitable for a spatial planning that tends to be centered (activity in the middle of the room), while the position of the roof monitor type 1 is more suitable for linear space arrangement with a circulation path in the middle of the room (dividing space into two functional zones).

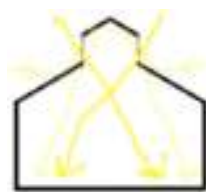

type 1

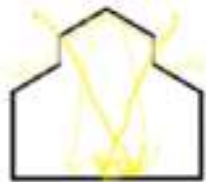

type 2

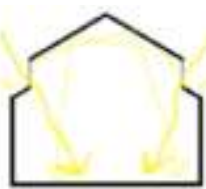

type 3
Figure 10. Light distribution visualization of roof monitor opening type

The Daylight Factor (DF) value is greater at openings with a longer distance (types 2 and 3 ) because, its height is lower according to the roof shape. Meanwhile, the opening type 1 position is far at the rooftop, therefore it has the smallest DF value. Roof monitor type 1 does not meet the minimum Daylight Factor value requirements for school, office or stadium functions. But, types 2 and 3, when viewed from the average DF value, still meet the requirements. However, the 
minimum DF value is still below that of the average recommended natural light factor.

The three types of roof monitors have a sufficient light uniformity value which is above the general standard requirements. For instance, high indoor reflection value has a significant contribution to produce light uniformity. Likewise, roof monitor type 1 has the highest light uniformity value $(\mathrm{CU} \min /$ average $=0.62)$. Meanwhile, the reference to the distance comparison between the openings and space height cannot be used to assess the opening type of the roof monitor because, the area is not in the horizontal plane. Basically, the opening position on the roof monitor type 1 is higher than the other types, thus, it causes a wider light distribution to space and increases the light uniformity value. The incoming light also accumulates on the central ceiling and is reflected throughout the space to help with light distribution. The aperture position in type 3 tends to direct light towards the space center, thereby causing light accumulation in the center of the space and increasing contrast. Therefore, the light uniformity value is lower than other types, although it can still be categorized fairly evenly because it is close to the standard value.

Comparison of DF value and light uniformity at sawtooth opening type

Table 4. Comparison of light contours and visualization of sawtooth type daylighting

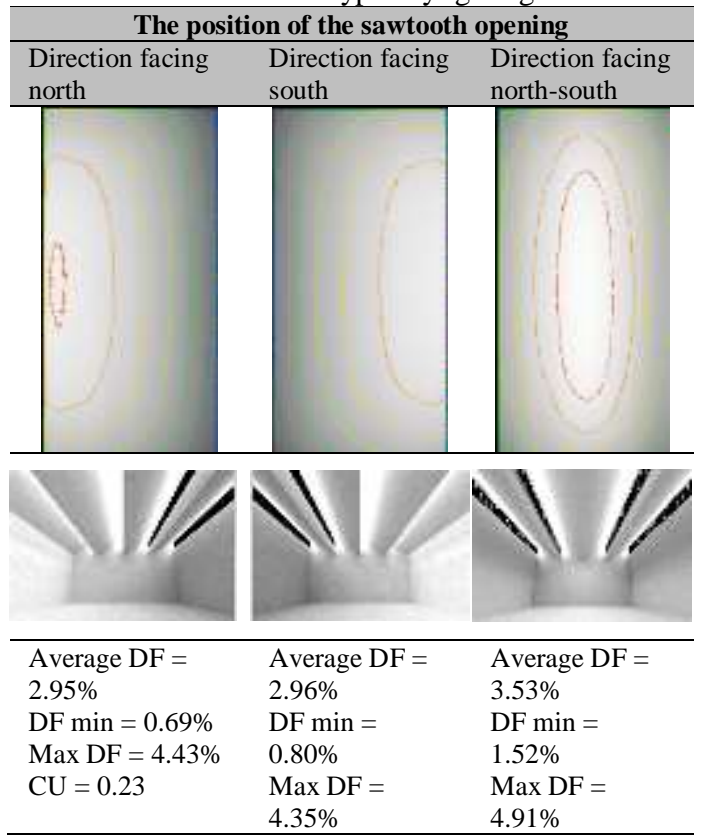

\begin{tabular}{lll}
\hline \multicolumn{3}{c}{ The position of the sawtooth opening } \\
\hline $\begin{array}{l}\text { Direction facing } \\
\text { north }\end{array}$ & $\begin{array}{l}\text { Direction facing } \\
\text { south }\end{array}$ & $\begin{array}{l}\text { Direction facing } \\
\text { north-south }\end{array}$ \\
\hline & $\mathrm{CU}=0.18$ & $\mathrm{CU}=0.43$
\end{tabular}

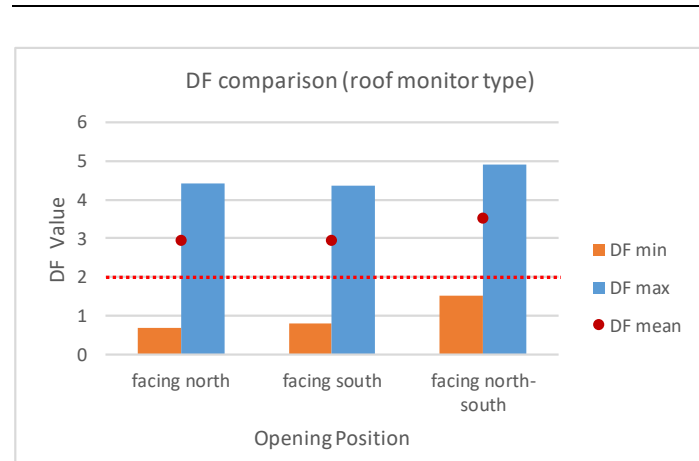

Figure 11. Comparison graph of DF value at the sawtooth type

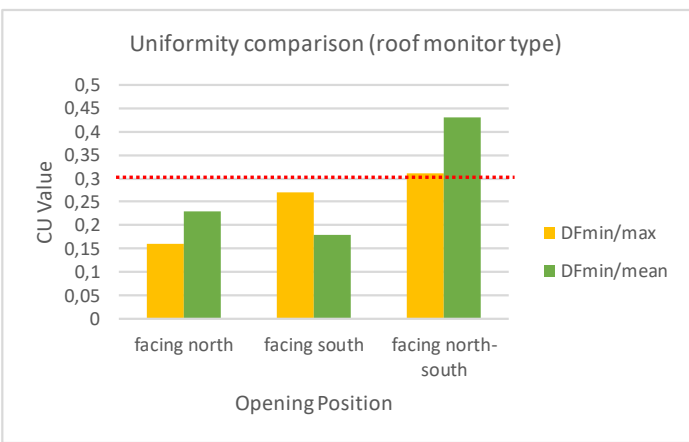

Figure 12. Comparison graph of the light uniformity value on the sawtooth type

The distribution pattern is formed according to the opening direction, for example, at opening to the north, light in the horizontal plane accumulates in the southern part of the space, and vice versa. Also, in the direction of the north and south combination openings, light is more evenly distributed throughout the space. Therefore, type 3 sawtooth has the potential for flexible inner space zoning arrangement compared to the other two types. Likewise, sawtooth types 1 and 2 will be more suitable for space functions that require lighting in the vertical plane (walls). 


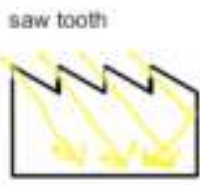

type 1

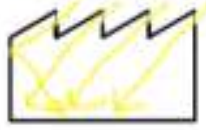

type 2

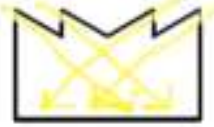

type 3
Figure 13. Light distribution visualization of sawtooth opening type

The Daylight Factor value is slightly larger in the direction of the combination opening because, the incoming light directly illuminates the horizontal plane. Whereas, in the other two types, some of the incoming light is reflected first through the wall plane before illuminating the horizontal plane. The three types of sawtooth openings had an average DF value of more than $2 \%$, however, the sawtooth type that was oriented in one direction had a dark area with a fairly low minimum DF value.

The sawtooth type with the combination opening direction has the highest light uniformity value of 0.43 , because, the distribution is more evenly distributed throughout the horizontal direction of the space. While the other two types only have one orientation toward the aperture, thus, the light builds up in one direction, thereby causing dark areas in the other.

Comparison of daylighting performance on skylight, roof monitor, and sawtooth openings

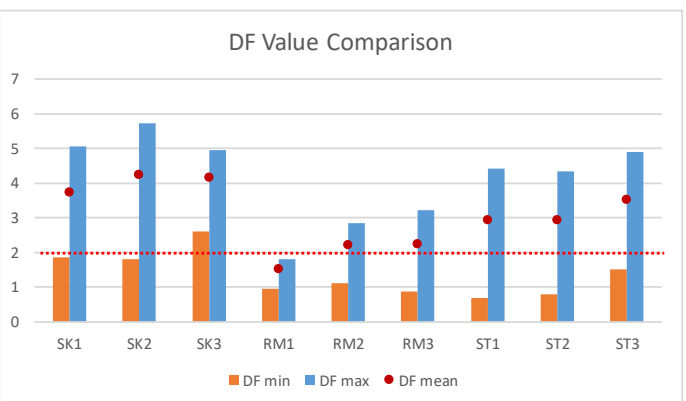

Figure 14. Comparison of DF values on the three types of toplighting

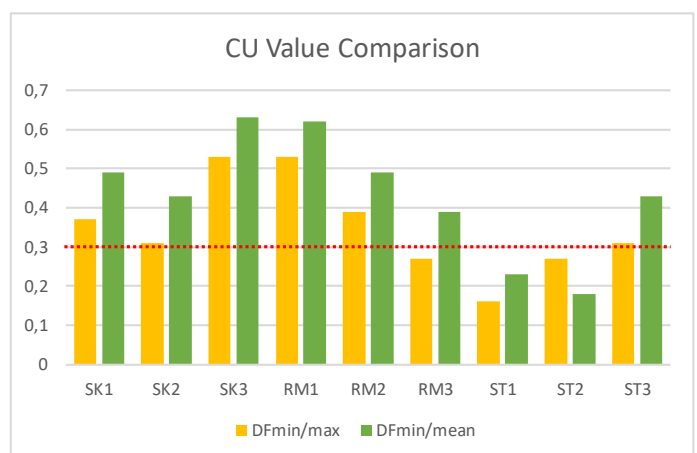

Figure 15. The CU values comparison of the three types of toplighting

Table 5. Designation description of the toplighting type

\begin{tabular}{|c|c|c|}
\hline Code & Toplighting type & Opening Position \\
\hline SK1 & \multirow{3}{*}{ Skylight } & $\begin{array}{l}\text { Opening position on the } \\
\text { rooftop }\end{array}$ \\
\hline SK2 & & $\begin{array}{l}\text { Opening position in the } \\
\text { center of the roof }\end{array}$ \\
\hline SK2 & & $\begin{array}{l}\text { Opening position at the } \\
\text { edge of the roof }\end{array}$ \\
\hline RM1 & \multirow{3}{*}{ Roof monitor } & Opening distance $6 \mathrm{~m}$ \\
\hline RM2 & & Opening distance $10 \mathrm{~m}$ \\
\hline RM3 & & Opening distance $16 \mathrm{~m}$ \\
\hline ST1 & \multirow{3}{*}{ Sawtooth } & $\begin{array}{l}\text { The opening direction } \\
\text { towards the north }\end{array}$ \\
\hline ST2 & & $\begin{array}{l}\text { The opening direction } \\
\text { towards the south }\end{array}$ \\
\hline ST3 & & $\begin{array}{l}\text { The opening direction } \\
\text { towards the north and } \\
\text { south }\end{array}$ \\
\hline
\end{tabular}

Based on the distribution patterns analysis and performance of the three openings types above, the following points of comparison were found:

1. Distribution pattern

Variations in distribution patterns are influenced by the type, position (height and distance between openings), slope, and opening direction. The designer can determine the type of toplighting to be used based on the needs of the space orientation/zoning division.

Table 6. Recommendations for selecting types of openings according to spatial orientation requirements

\begin{tabular}{lll}
$\begin{array}{l}\text { Space zoning } \\
\text { requirements }\end{array}$ & Light need & Recommendation \\
\hline $\begin{array}{l}\text { Orientation in } \\
\text { all directions } \\
\text { (flexible) }\end{array}$ & $\begin{array}{l}\text { Bright evenly in } \\
\text { all directions }\end{array}$ & ST3 \\
\hline $\begin{array}{l}\text { Orientation to } \\
\text { the center of } \\
\text { space }\end{array}$ & $\begin{array}{l}\text { Light } \\
\text { concentrated in } \\
\text { the center of } \\
\text { space }\end{array}$ & SK1, SK2, RM 2, \\
\hline $\begin{array}{l}\text { Orientation to } \\
\text { both edges of } \\
\text { space }\end{array}$ & $\begin{array}{l}\text { Light on both } \\
\text { edges of space }\end{array}$ & RM1, SK3 \\
\hline
\end{tabular}




\begin{tabular}{lll}
\hline $\begin{array}{l}\text { Space zoning } \\
\text { requirements }\end{array}$ & Light need & Recommendation \\
\hline $\begin{array}{l}\text { Orientation to } \\
\text { one edge of } \\
\text { the space with }\end{array}$ & $\begin{array}{l}\text { Light on one } \\
\text { edge of the } \\
\text { room and high }\end{array}$ & ST1, ST2 \\
$\begin{array}{l}\text { an emphasis of the } \\
\text { wall planes }\end{array}$ & $\begin{array}{l}\text { contrast on one } \\
\text { wall }\end{array}$ & \\
\hline
\end{tabular}

2. Daylight factor value

All aperture variants (except type RM1) meet the requirements for an average Daylight Factor (DF) value of $2 \%$. As well as the minimum, maximum, and the highest average DF values for the skylight opening and the lowest on the roof monitor. This is because the vertical opening in the sawtooth and roof monitor types includes a less direct skylight and a lot of reflected light, hence it is reduced (reflections from the roofceiling-work area). The variation in openings position on the roof monitor type is also placed higher than the sawtooth (following the slope of the roof), therefore, the DF value is getting smaller (the farther away from the work plane).

\section{Light uniformity value}

Light uniformity for all types of the skylight, roof monitor, and sawtooth openings is considered good because, it is quite even (almost all $\mathrm{CU}$ values are above 0.3 and $\mathrm{DF}$ min. Above $0.8 \%$ ). This emphasizes the role of the toplighting design strategy of achieving an even distribution of light throughout the space. Only the ST1 and ST2 types have light uniformity values slightly below 0.3 , and the minimum DF value for ST1 types is below $0.8 \%$ because, openings orientation is only in one direction. The light uniformity is also influenced by the value of indoor space reflection which in the simulation parameter is set with a high reflection coefficient.

\section{Conclusion}

Based on the exploration and evaluation of the three types of toplighting and comparing the distribution patterns of natural light and their performances, it can be concluded that the toplighting placement in a horizontal (skylight type) and a vertical position (roof monitor and sawtooth type), opening position (opening height and distance), as well as the opening direction are factors affecting the daylighting performance. In the early stages, the designer can choose from the three types of toplighting, based on orientation requirements according to the space function. The module used is an opening with a $16.3 \%$ of the effective roof area to meet the standard value of the Daylight Factor (above 2\%) for all variants of the toplighting (except for type RM1). In essence, the three types of openings have good light uniformity performance (CU values above 0.3 and DF min. above $0.8 \%$ in accordance to BREEAM requirements, except for ST1 and ST2 types). Therefore, it can be concluded that the opening type on the skylight is more effective in accommodating the daylighting performance of both the DF value and light uniformity. Space and openings model can be used as a reference for large-volume industrial buildings with the functions of sports halls, laboratories, and multipurpose rooms.

On the other hand, this research has limitations in the openings types and daylighting indicators. Hence, further findings can compare other openings types, variations in modules, or different composition arrangements. There are different types of space visualization and the opening position affects the brightness level of the elements that cover the space and creates a symmetrical and asymmetric light pattern. Thus, these results can be continued by carrying out research on the effect of light composition (dark/light) produced (through various types of opening designs) on the space perception or impression.

\section{References}

Acosta, Ignacio, Carmen Munoz, Miguel Angel Campano, and Jaime Navarro. 2015. 'Analysis of Daylight Factors and Energy Saving Allowed by Windows under Overcast Sky Conditions'. Renewable Energy 77 (May): 194-207. https://doi.org/10.1016/j.renene.2014.12.017.

Al-Obaidi, Karam M., Mazran Ismail, and Abdul Malek Abdul Rahman. 2014. 'Energy Efficient Skylight Design in Tropical Houses'. Key Engineering Materials 632 (November): 45-56. https://doi.org/10.4028/www.scientific.net/K EM.632.45.

Ali, Safira. 2014. 'Pengaruh Elemen Desain Tapak Dan Bangunan Terhadap Performa Pencahayaan Alami Pada Lapangan 
Bulutangkis Indoor Bumi Pancasona KBP Bandung'. Universitas Katolik Parahyangan.

Ander, Gregg D. 2003. Daylighting Performance and Design. 2nd ed. New York: John, Wiley \& Sons, Inc.

Anthony, Sholanke, Pela Ogheneyoma, Pirisola Heritage, Ogunsade Ayoola, and Akerele Fiyinfoluwa. 2020. 'Daylight Penetration in Buildings: Issues in Tropical Climates'. Solid State Technology $63 \quad$ (2s). http://solidstatetechnology.us/index.php/JSS T/article/view/1550.

Asdrubali, F. 2003. 'Daylighting Performance of Sawtooth Roofs of Industrial Buildings'. Lighting Research \& Technology 35 (4): 34358. https://doi.org/10.1191/1365782803li094oa.

Barbrow, L. E. 1964. 'International Lighting Vocabulary'. Journal of the SMPTE 73 (4): 331-32. https://doi.org/10.5594/J07262.

Barret, Richard. 2009. 'The Case for Daylighting in Architecture'. IArchNet-IJAR: Nternational Journal of Architectural Research 3 (2). https://archnet.org/publications/5248.

Beltran, Liliana O. 2005. 'Toplighting for the Tropics'. In Passive and Low Energy Architecture - Environmental Sustainability: The Challenge of Awareness in Developing Societies, 1-4. Beirut Lebanon: 22nd International Conference, PLEA. https://faculty.arch.tamu.edu/media/cms_pag e_media/2884/LBeltran_PLEA2005.pdf.

BRE Global. 2013. 'BREEAM UK New Construction'. Issuu. 2013. https://issuu.com/syntegra/docs/sd5076breeam-uk-new-construction-2.

Chen, Yuanyi, Junjie Liu, Jingjing Pei, Xiaodong Cao, Qingyan Chen, and Yi Jiang. 2014. 'Experimental and Simulation Study on the Performance of Daylighting in an Industrial Building and Its Energy Saving Potential'. Energy and Buildings 73 (April): 184-91. https://doi.org/10.1016/j.enbuild.2014.01.030

Edwards, L., and P. Torcellini. 2002. 'A Literature Review of the Effects of Natural Light on Building Occupants'. Colorado. https://www.nrel.gov/docs/fy02osti/30769.pd f.

Egan, David, and Victor Olgyay. 2001. Architectural Lighting. Ohio: McGraw-Hill Science.

Farley, K. M. J, and Jennifer A. Veitch. 2001. 'A Room With A View: A Review of the Effects of Windows on Work and Well-Being'. Canada.

https://doi.org/https://doi.org/10.4224/203789 71.

Heschong, Lisa. 2002. 'Daylighting and Human Performance'. ASHRAE Journal, 65-67. http://www.livingdaylights.nl/wpcontent/uploads/2016/12/Heschong-2002.Daylighting-and-Human-performance..pdf.

Iversen, Anne, Nicolas Roy, Mette Hvass, Michael Jørgensen, Jens Christoffersen, Werner Osterhous, and Kjeld Johnsen. 2013. Daylight Calculations in Practice: An Investigation of the Ability of Nine Daylight Simulation Programs to Calculate the Daylight Factor in Five Typical Rooms. 1st ed. Copenhagen: Danish Building Research Institute.

Kementrian Pemuda dan Olahraga RI. 2014. Peraturan Mentri Pemuda Dan Olahraga Republik Indonesia Tentang Standar Prasarana Olahraga Berupa Bangunan Gedung Olah Raga. Indonesia.

Kementrian Perindustrian RI. 2010. Peraturan Mentri Perindustrian Republik Indonesia Tentang Pedoman Teknis Kawasan Industri. Indonesia.

Lapisa, Remon, Arwizet Karudin, M. Martias, K. Krismadinata, A. Ambiyar, Zaid Romani, and Patrick Salagnac. 2020. 'Effect of SkylightRoof Ratio on Warehouse Building Energy Balance and Thermal-Visual Comfort in HotHumid Climate Area'. Asian Journal of Civil Engineering $21 \quad$ (5): 915-23. https://doi.org/10.1007/s42107-020-00249-9.

Lawrence, Tyson, Kurt Roth, Drudy B. Crawley, and James Brodrick. 2008. 'Toplighting \& Lighting Controls for Commercial Buildings'. ASRAE Journal $50 \quad$ (9). https:/go.gale.com/ps/i.do?id=GALE\%7CA2 $01032390 \&$ sid $=$ googleScholar $\& v=2.1 \& i t=r$ $\&$ linkaccess $=$ abs $\&$ issn $=00012491 \& p=A O N E$ $\& \mathrm{sw}=$ w\&userGroupName=anon $20 \mathrm{a} 21 \mathrm{f83}$.

Lechner, Norbert. 2008. Heating, Cooling, Lighting: Sustainable Design Methods for Architects. 3rd ed. New Jersey: John, Wiley \& Sons, Inc.

Luca, Francesco De, Raimo Simson, Hendrik Voll, and Jarek Kurnitski. 2018. 'Daylighting and Energy Performance Design for Single Floor Commercial Hall Buildings'. Management of Environmental Quality: An 
International Journal 29 (4): 722-39. https://doi.org/10.1108/MEQ-10-2017-0110.

Mandala, Ariani. 2020. Metode Perhitungan dan Simulasi Pencahayaan Alami Dalam Bangunan. EC00202008536, issued 2020.

Mandala, Ariani, and Amirani Ritva Santoso. 2018. 'Comparative Study of Daylighting Calculation Methods'. Edited by R.B. Santosa, N.C. Idham, N.G. Yuli, and P.AP. Agustiananda. SHS Web of Conferences 41 (January):

06001. https://doi.org/10.1051/shsconf/20184106001

Mandala, Ariani, Amirani Ritva Santoso, and Ryani Gunawan. 2016. 'Komparasi Metode Perhitungan Pencahayaan Alami (Perhitungan Manual, Simulasi Maket, Dan Simulasi Komputer)'. Bandung. https://repository.unpar.ac.id/bitstream/handl e/123456789/797/LPD_Ariani_Komparasi_ Metode_Perhitunganp.pdf?sequence $=1 \&$ is Allowed $=\mathrm{y}$.

Mansfield, KP. 2018. 'Architectural Lighting Design: A Research Review over 50 Years'. Lighting Research \& Technology 50 (1): 8097. https://doi.org/10.1177/1477153517736803.

Neufert, Ernst, and Peter Neufert. 2000. Architect's Data. Edited by Bousmaha Baiche and Nicholas Walliman. 3rd ed. Oxford, England: Blackwell Science.

Nezamdoost, Amir, Rachel Cui, Alen Mahic, Joelle Mbala-Nkanga, Haley Nelson, and Kevin Van Den Wymelenberg. 2017. 'A Comparative Study on Toplighting Strategies in an Academic Building'. In IES Annual Conference Proceedings, 1-12. Portland, Maine, United States: Illuminating
Engineering Society. https://amirnezamdoost.files.wordpress.com/ 2017/08/comparativestudy_toplighting_new-format.pdf.

Phillips, Derek. 2004. Daylighting: Natural Light In Architecture. Oxford, England: Elsevier Ltd.

Rahmah, Adhelia Adjani, and Wafirul Aqli. 2020. 'Konsep Arsitektur Biomimetik Pada Bangunan Oseanarium'. ARTEKS: Jurnal Teknik Arsitektur 5 (2): 297-306. https://doi.org/10.30822/arteks.v5i2.442.

Singh, Pooja. 2018. 'Built Architecture: The Role of Natural Light'. INTERNATIONAL JOURNAL OF RESEARCH AND ANALYTICAL REVIEWS 5 (3): 55-59. https://www.ijrar.org/papers/IJRAR1903257. pdf.

Zain-Ahmed, A, K Sopian, M.Y.H Othman, A.A.M Sayigh, and P.N Surendran. 2002. 'Daylighting as a Passive Solar Design Strategy in Tropical Buildings: A Case Study of Malaysia'. Energy Conversion and Management 43 (13): 1725-36. https://doi.org/10.1016/S01968904(01)00007-3.

\section{Author(s) contribution}

Ariani Mandala contributed to the research concepts preparation, methodologies, investigations, data analysis, visualization, articles drafting and revisions.

E. B. Handoko Sutanto contribute to methodology, supervision, and validation.

Amirani Ritya Santoso contribute to methodology, supervision, and validation. 
ARTEKS : Jurnal Teknik Arsitektur, Volume 6 Issue 2, August 2021

pISSN 2541-0598; eISSN 2541-1217 